\title{
Lithological varieties along the Vladayska River on the territory of Sofia
}

\section{Литоложки разновидности по поречието на Владайска река на територията на София}

\author{
Yordanka Donkova \\ Йорданка Донкова \\ Geological Institute, Bulgarian Academy of Sciences, 1113 Sofia; E-mail: idonkovaa@abv.bg
}

\begin{abstract}
Along the Vladayska River on the territory of Sofia are analyzed Quaternary sediments from five different sites (24 samples). On the base of this investigation are composed two three-component diagrams to define the sedimentary varieties. To determine the sedimentary environments (river channel or overbank deposits) in studied area are used relationships between structural parameters $\mathrm{Mz}, \sigma 1$ and Sk.
\end{abstract}

Keywords: lithological varieties, Quaternary sediments, Vladayska River, Sofia.

\section{Въведение}

Обработени са 24 броя проби кватернерни седименти от 5 различни обекта по поречието на Владайска река на територията на София: разкритие в квартал „Княжево“, сондажи от квартали ,Зона Б-5“ и квартал „Сердика“, археологически обект на ул. „Екзарх Йосиф“ № 35 и са ползвани данни за археологически обект на ул. „Цветан Минков“ № 12 от Todorova et al. (2020). Взетите материали са подложени на пълен набор седиментоложки анализи, като в настоящото съобщение са представени само литоложките разновидности и седиментационните обстановки на формиране на кватернерните отложения.

\section{Резултати}

\section{Литоложки разновидности}

Използвани са две трикомпонентни диаграми по класификациите на Folk (1954) (фиг. 1a) и Schlee (1973) (фиг. 1б). По първата диаграма седиментите се поделят на 8 разновидности (фиг. 1a). Най-голяма част от тях се определят като глинесто-песъчливи чакъли (археологически обект на ул. „Екзарх Йосиф“ № 35 и квартал „Княжево“), на второ място по разпространение са глинесточакълести пясъци (квартал ,Зона Б-5“, квартал „Сердика“" и археологически обект на ул. Екзарх Йосиф № 35), следват: слабо чакълесто-глинести пясьци (квартал „Сердика“" и археологически обект на ул. „Екзарх Йосиф“ № 35), песъчливи чакъли (археологически обект на ул. „Екзарх Йосиф“ № 35) и глинести пясъци (квартал „Сердика" $\left.{ }^{6}\right)$. Пробите от археологически обект на ул. „Цветан Минков“ № 12 са определени като чакълести глини, слабо чакълести песъчливи глини и песъчливи глини. Според втората диаграма седиментите биват 5 разновидности (фиг. 1б). С най-голям дял са песъчливите седименти (археологически обект на ул. „Екзарх Йосиф“ № 35, квартал „Княжево“ и квартал „Сердика“), следват песъчливите глини (археологически обект на ул. „Цветан Минков“ № 12), с еднакво разпространение са чакълите (археологически обект на ул. „Екзарх Йосиф“ № 35), пясъците (квартал „Зона Б-5“ и квартал „Сердика“) и глинестите пясьци (археологически обект на ул. „Екзарх Йосиф““ № 35).

\section{Седиментационни обстановки}

За да бъдат определени седиментационните обстановки на две отделни графики са представени връзките между структурните параметри $\mathrm{Mz}$ (среден размер), б1 (стандартно отклонение) и Sk (симетрия на разпределение) (фиг. 1в, г). Отделени са две обстановки на формиране: руслови и на заливни тераси. Като руслови седименти се определят основната част от пробите от археологическия обект на ул. „Екзарх Йосиф“ № 35, квартал „Княжево“ и най-горното ниво от сондажа при квартал „Сердика“. Седиментите на заливните тераси са установени в квартал „Зона Б-5“, квартал „Сердика“ и в една 

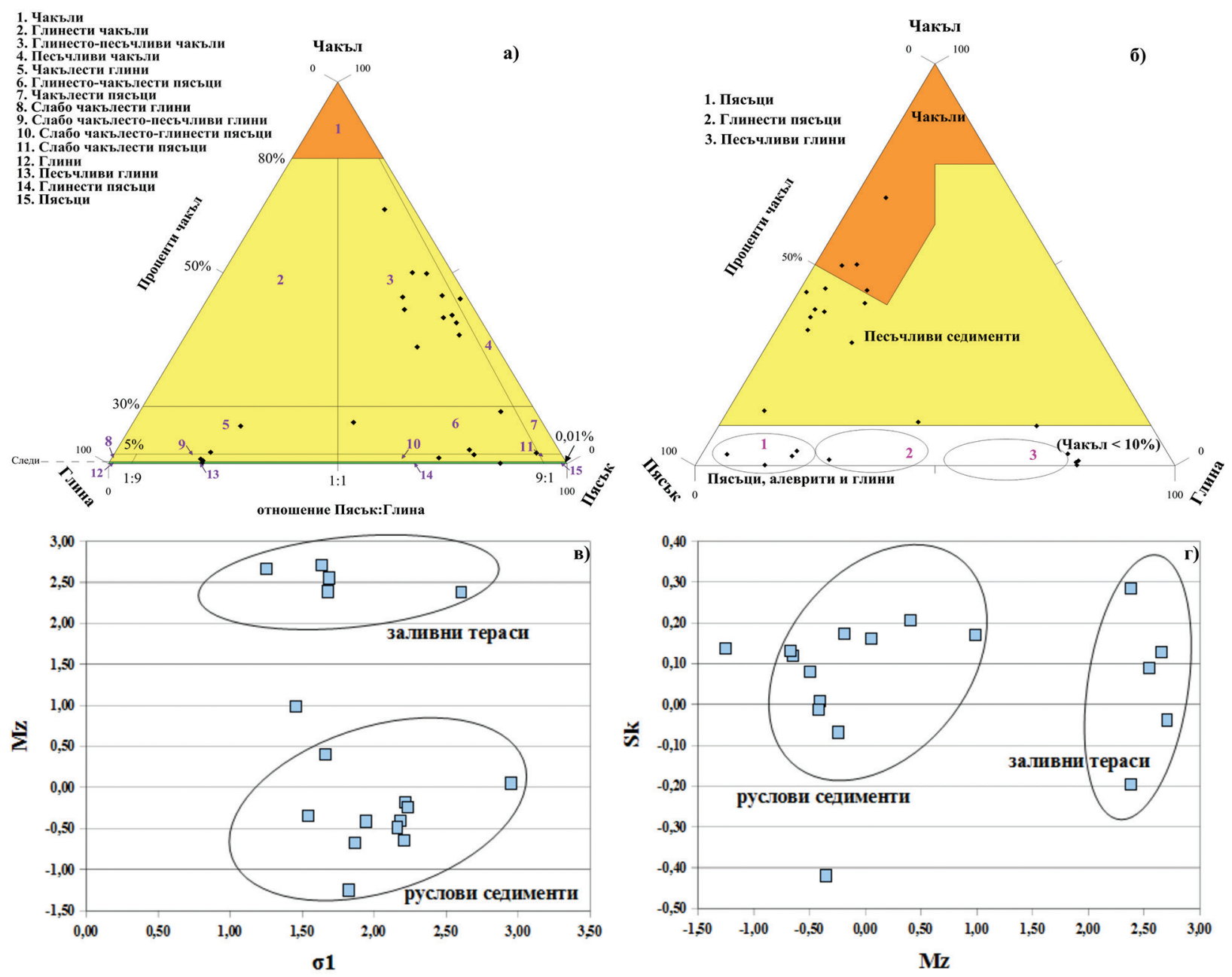

Фиг. 1. Класификационни диаграми глина-пясък-чакъл: $a$, по Folk (1954); б, по Schlee (1973); връзка между структурните параметри по Mycielska-Dowgiałło \& Ludwikowska-Kędzia (2011): в, Mz и б1; г, Sk и Mz

проба от археологическия обект на ул. „Екзарх Йосиф“ № 35.

\section{Заключение}

Седиментният материал по поречието на Владайска река е изключително разнообразен. Представен е от различни вариации от чакъли, пясъци и глини. С най-голямо площно разпространение и количества са пясъците, следвани от глини и в по-малка част от чакъли. Чакълите са установени в по долните нива на сондажите при квартал „Зона Б-5“, квартал „Сердика“, както и в археологически обект на ул. „Екзарх Йосиф“ № 35. Пясьците преобладават в горните нива на същите сондажи. Единствено при археологическия обект на ул. „Цветан Минков“ № 12 седиментите са представени от различни разновидности глини. Това се дължи на непосредствената близост на обекта до Владайска река. Русловите седименти са в по-големи количества спрямо тези на заливните тераси, като те са кон- центрирани в двата археологически обекта и в най-горните нива на сондажите при кварталите „Княжево“ и „Сердика“. Седиментите на заливните тераси доминират в сондажите при кварталите „Зона Б-5“ и „Сердика“.

\section{Литература \\ References}

Folk, R.L. 1954. The distinction between grain size and mineral composition in sedimentary rock nomenclature. - J. Geol,. $62,4,344-359$.

Mycielska-Dowgiałło, E., M. Ludwikowska-Kędzia. 2011. Alternative interpretations of grain-size data from Quaternary deposits. - Geologos, 17, 4, 189-203.

Schlee, J. S. 1973. Atlantic continental shelf and slope of the United States; sediment texture of the northeastern part. Geological Survey Professional Paper 529-L, 64 p.

Todorova N., V. Petrova, N. Atanasova, M. Yaneva. 2020. The well-known and the unknown muslim cemetery near Draz mahala. New data from archaeological and anthropological investigation in 2017. - In: Edition of National Scientific Conference "90 years - Sofia Museum" ("Serdika - Sredets - Sofia”), 2018, 8 (in Bulgarian with English abstract). 